\title{
Los gestos de poder divino en la imaginería Ibérica
}

\author{
$M^{a}$ Paz García-Bellido \\ CSIC, Madrid
}

"Los egipcios ofrecen a los dioses ojos y orejas de materiales costosos para mostrar que dios todo lo ve y todo lo oye" Clemente de Alejandría, Stromata V, 7, 42, (p. 354 Staehlin).

\section{Resumen}

El estudio de los gestos de los exvotos ibéricos me lleva a suponer que las frecuentes hipertrofias de sus miembros constituyen la mímica sagrada necesaria para mostrar que se trata de divinidades epékooi, que escuchan, panóptai - panderkeîs, que todo lo ven y doteîrai, dadivosas, que proporcionan bienes. Muchos de los exvotos ibéricos podrían representar dioses y no devotos.

Palabras clave: prerromano, ibérico, iconografía, santuarios, Jaén, Murcia.

\begin{abstract}
We believe that the frequent hypertrophy of body parts found in Iberian votive figures represent the sacred mimic used to show that they are divinities epekooi (i.e., who listen), panóptai - panderkeîs, (all seeing) and doteîrai (allgiving). Many of the so called Iberian 'votive' figures could in fact represent divinities rather than worshippers.

Keywords: Iberian Iron Age. Iconography. Sanctuaries. Jaén. Murcia.
\end{abstract}

Es mucho lo que ignoramos sobre el significado de los gestos en la imaginería divina antigua, a pesar de que para numerosas representaciones conocemos muy bien el historial de sus personajes gracias a las narraciones míticas. Los gestos han jugado parte principal en las representaciones figuradas de estas narraciones literarias. Los oyentes de los cuentos y espectadores de las imágenes han transmitido a las siguientes generaciones el contenido literario y figurativo de estas narraciones divinas y hoy, para algunas de ellas, conocemos todos los códigos de interpretación. Sin embargo, para muchas otras desconocemos el mito y con ello el lenguaje de sus representaciones figuradas, por lo que estamos realmente perdidos a la hora de interpretar los

\footnotetext{
${ }^{1}$ Esta ha sido la interpretación generalizada de los exvotos ibéricos, y de la diferente calidad artística y tipos de
}

iconos que los antiguos nos han legado, desposeídos para nosotros de cualquier iconología.

Este es el caso de la cultura ibérica. De hecho no tenemos dioses ibéricos, ninguna de sus esculturas, ninguno de sus exvotos han sido interpretados como divinidades, sino todos ellos como representantes de las diferentes clases sociales de los devotos. "Damas" o "caballeros" de alta alcurnia en las esculturas en piedra $y$, en los pequeños exvotos de bronce, diferentes clases sociales, juzgando la distinta calidad de lo figurado como testimonio de las varias clases que convivirían. Así se representarían, ellos mismos, en los diferentes santuarios ibéricos o en las tumbas más lujosas, siendo su propia imagen la que ofrecían a los dioses ${ }^{1}$.

vestido se ha concluido que la sociedad ibérica estaba profundamente jerarquizada. R. Lantier, Bronzes votifs 

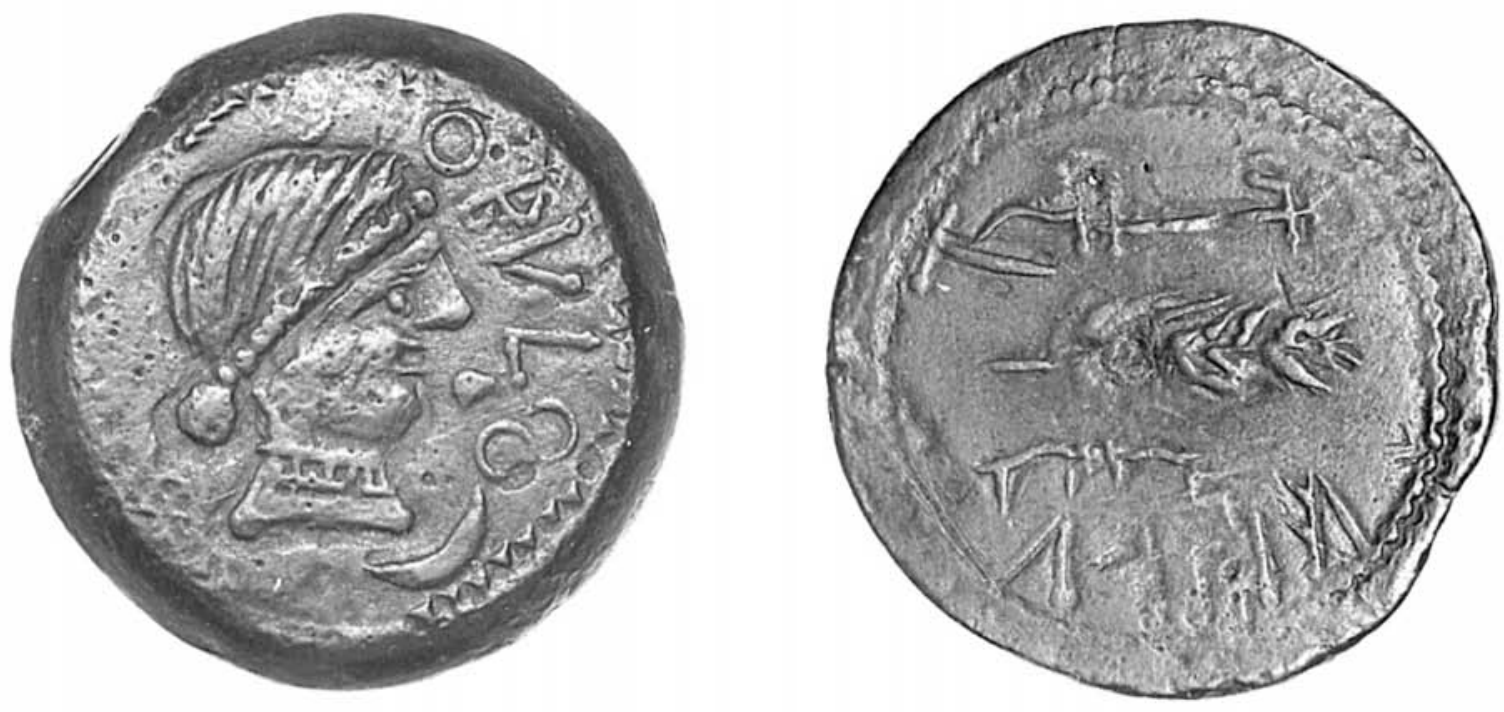

Fig. 1: a) As de Obulco.- Anv. divinidad femenina con moño y collar, debajo creciente lunar, delante OBVLCO/ rev. Arado, espiga y yugo, debajo topónimo ibolka en escritura ibérica. Col. IVDJ.

A pesar de la rica gama de la escultura ibérica nunca se ha calificado de divino ninguno de sus ejemplares. Hoy por hoy es una cultura sin dioses aún cuando posee una espléndida calidad monumental que falta sin embargo en otras muchas culturas mediterráneas. Todas las representaciones escultóricas, mayores y menores, se han interpretado como las imágenes de las elites en rituales de iniciación, de ofrenda o actitudes lúdicas. Creo sin embargo que la supuesta carencia de representaciones divinas podría deberse simplemente a nuestra incapacidad para detectar sus imágenes, de las que los exvotos serían una parte de sus simulacros.

\section{¿HEMOS HECHO BIEN LA LECTURA DEL MUNDO DIVINO IBÉRICO?}

Para la interpretación iconográfica de la imaginería divina de los pueblos antiguos ha sido capital el disponer de una suficiente cantidad de imágenes que permitiera crear el prototipo, y contar con abundantes textos literarios o epigráficos de carácter mítico o cultual. Desgraciadamente las fuentes escritas han sido muy parcas para algunas culturas e inexistentes para otras, bien porque su literatura se haya perdido, bien porque ciertos pueblos no dispusieron de una literatura religiosa, ni de usos epigráficos para

ibériques, Paris 1935; F. Alvarez Ossorio, Catálogo de los exvotos de bronce ibéricos del Museo Arqueológico Nacional, Madrid 1941; G. Nicolini, Les bronzes figurés des sanc- este fin. Este es el caso de los íberos. Por añadidura, muchos de estos pueblos que indudablemente habían conformado una iconografía, ella no trascendió los límites culturales del propio pueblo, pues aunque se habían creado iconos representativos en ciertos territorios y grupos culturales, su amplitud era reducida, faltando un lenguaje mítico vehicular en amplios contextos. Estas representaciones iconográficas son barridas y caen en olvido cuando la cultura greco-latina hace su aparición. Es evidente que el éxito o el fracaso de la creación de un código de lenguaje iconográfico radica en la eficacia y amplitud de su transmisión. Esta eficacia y esta amplitud son las que acompañaron desde fechas muy tempranas a la iconografía griega y ella se sobrepuso en las clases sociales más altas de las otras culturas, gracias a la importación de los objetos de lujo griegos, sobre todo de la cerámica figurada. La importación de materiales figurados griegos acabó substituyendo casi totalmente las iconografías de los diferentes pueblos mediterráneos.

Los griegos codificaron muy pronto su lenguaje iconográfico: las imágenes, los gestos y los símbolos. Homero y Hesiodo ponen orden en el mito griego y proporcionan una serie de epítetos literarios y descripciones minuciosas de objetos simbólicos, representativos de la divinidad, que

tuaires ibériques, Paris 1969; L. Prados, Exvotos ibéricos de bronce del Museo Arqueológico Nacional, Madrid 1992. 


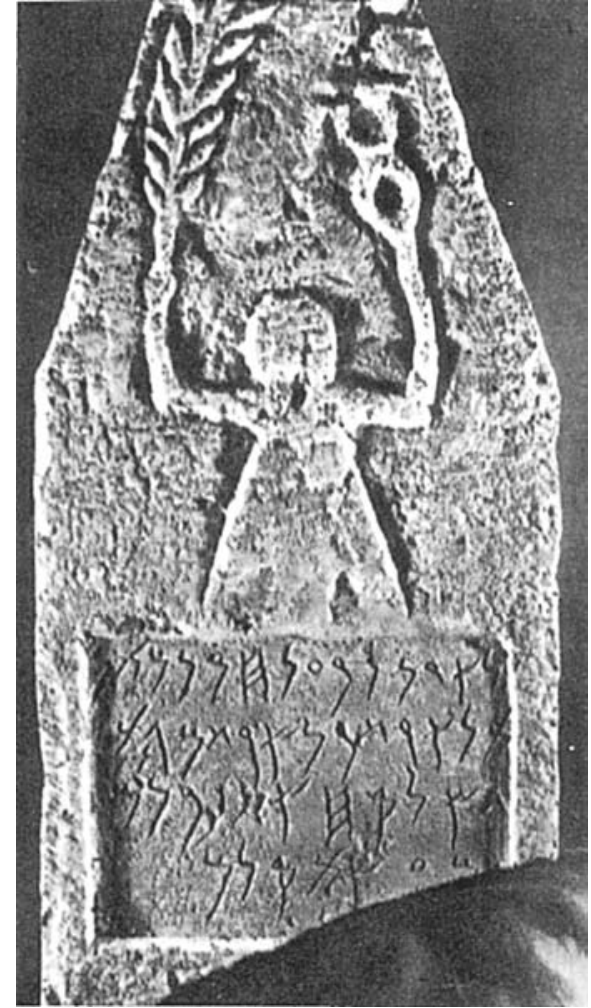

Fig. 2: Estela con Símbolo Tinit con caduceo y espigas. Santuario de El Hofra (Constantina).

la cerámica figurada casi al mismo tiempo comienza a ilustrar. Relato e imagen se transmiten desde el s. VIII por todo el Mediterráneo, configurando entrambos un código iconográfico que se aceptará y se utilizará para iconologías de otros pueblos que no les corresponden. Esta es la razón por la que durante siglos de estudios arqueológicos hemos interpretado como divinidades helénicas todas aquellas representaciones vestidas a la griega, aunque nada tuvieran que ver con el mito griego. Esto ha resultado ser una fatalidad para el conocimiento y la comprensión de los fenómenos religiosos no griegos, pero hemos de reconocer que ese desvío en la inter- pretación iconológica ha sido preferible a nuestra sensación de impotencia frente a iconografías que nada tienen que ver con la clásica; al menos ese ropaje griego nos proporcionaba una información sobre el carácter de la divinidad vestida a la griega, y nos permitía diferenciar dioses de devotos eso que, como veremos, tan críptico nos resulta con la imaginería ibérica.

En general, en las fases previas en que estos pueblos mediterráneos no utilizan la iconografía griega, se ha recurrido a un sistema sin estructurar de símbolos acumulativos que, como los adjetivos, se colocan en ristra para que alcancen a dar todo el contenido religioso de la divinidad que ilustran. Es el caso de las representaciones monetales que, a pesar del escaso campo del que disponen, acumulan información para ser explícitas (fig. 1). La divinidad de Obulco es femenina por los collares y el peinado y celeste por los astros que la acompañan. Protege el trabajo del campo a juzgar por el arado y el yugo que ilustra, haciéndolo frugífero como la espiga muestra. Este complejo lenguaje acumulativo se trasmite en el lenguaje griego con solo coronar de espigas la cabeza de la diosa Ceres, cuya esencia es perfectamente conocida por el fiel. De la misma manera, en la literatura, los epítetos divinos, constatados ya en Homero, definen a la divinidad mucho mejor que una larga paráfrasis descriptiva. Este es el caso del epíteto epékoos utilizado en los epígrafes griegos, para el que sin embargo los púnicos necesitan de una larga frase "A ... porque oyó la voz de su plagaria y le bendijo", como vemos en las estelas.

Este barroquismo de muchas culturas mediterráneas es efectivamente el contrapunto de la iconografía griega, con su parquedad y mesura de gestos y símbolos, creciente a medida que nos acercamos al helenismo en que los dioses pierden los gestos de poder que habían poseído en tiempos arcaicos. ¿’Por qué los griegos pudieron mantener esta sofrosine en el lenguaje iconográ-
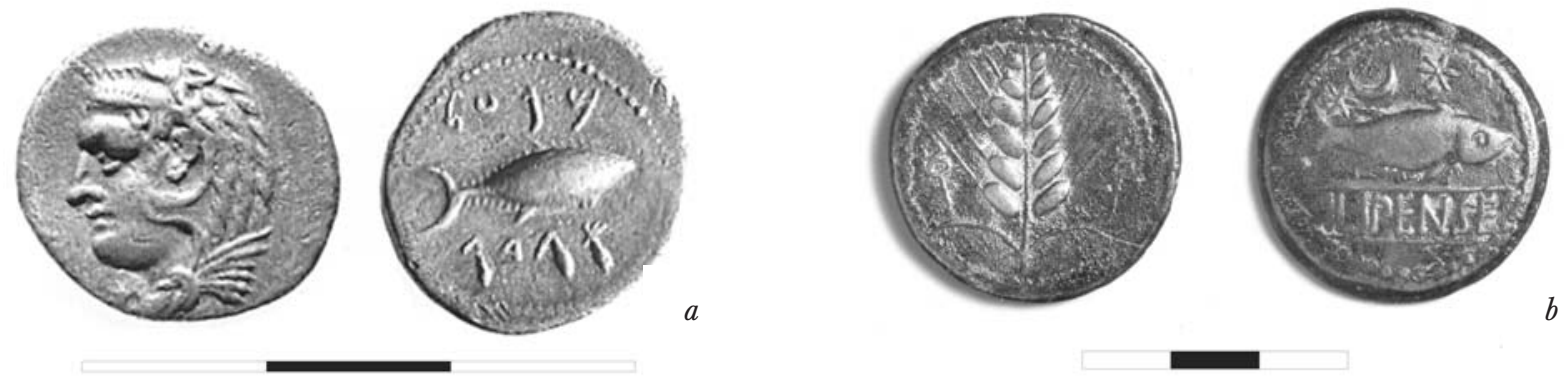

Fig. 3.-a) Melkart en la moneda de Gades b) Tinit en las monedas de Ilipa: anv. Espiga entre caduceos/ rev. Sábalo y astros, entre líneas ILIPENSE. Col. IVDJ. 


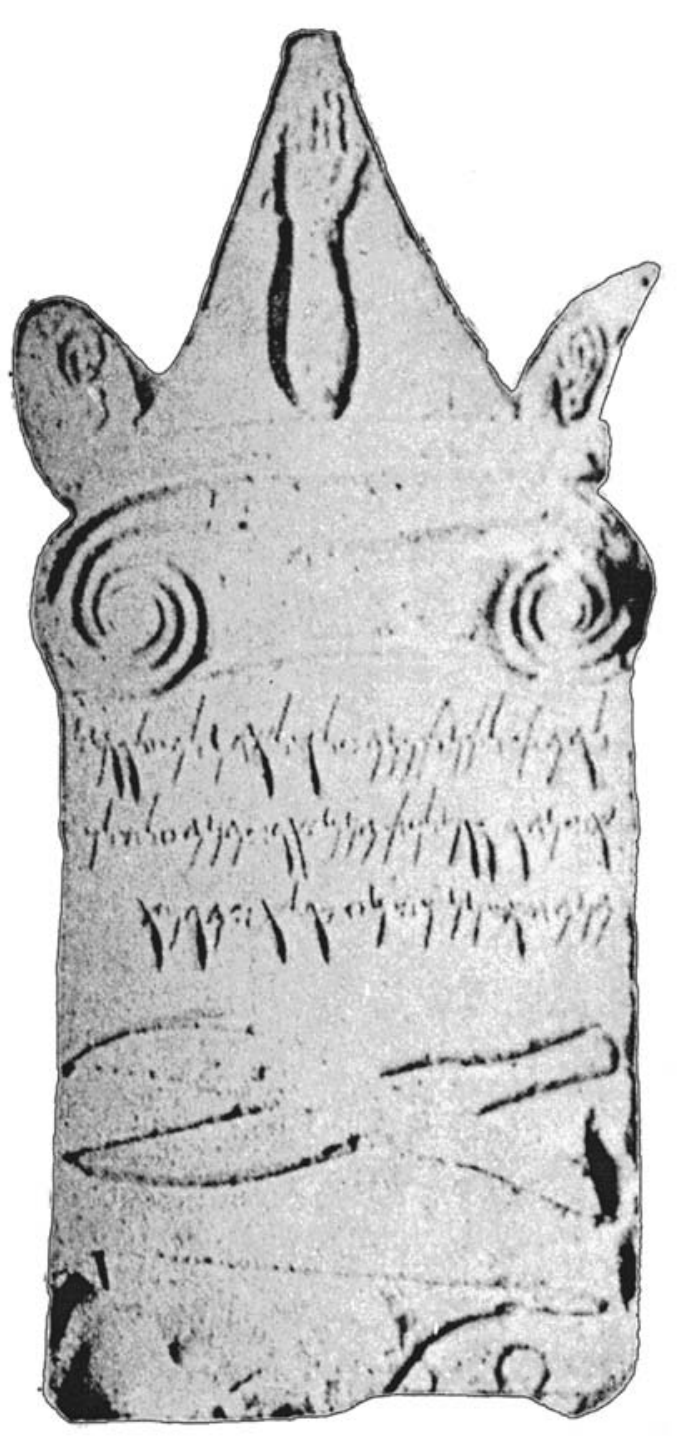

Fig. 4: Estela con representación de orejas en las acróteras y mano y brazo derecho (Museo del Bardo, cb 658).

fico mítico? Sin duda porque el usuario sabía interpretar la iconología de lo que veía gracias a la conocida relación entre mito e imagen, aun cuando fuese a través de una muy parca información de mímica y símbolos.

Muchas otras culturas importantes, y me refiero ahora a la cartaginesa por haber sido con la griega un factor trascendente en la formación de la cultura ibérica, no supieron establecer un perdurable código de lenguaje iconográfico, en gran parte porque los griegos se lo dieron hecho, y ello abortó el desarrollo que se estaba produ-

2 A. Berthier \& R. Charlier, Le sanctuaire d'El Hofra à Constantine, Paris 1955, Pl. 12,A. Para las monedas of. M.P. García-Bellido \& C. Blázquez, Diccionario de cecas y pueblos hispánicos (DCyP) Madrid 1991, s.v. ciendo en la propia Cartago. El arte griego en el período helenístico cubrió todos los centros urbanos del Mediterráneo, creando una koiné iconográfica culta que suplantó las formas locales en la mayor parte de las culturas implicadas. Sin embargo, en el mundo de las estelas púnicas existía un código ya establecido, símbolos y gestos que se repiten en relieves y monedas, indicando sin duda que había habido un lenguaje iconográfico general previo al helenismo, que permaneció vivo entre ciertas capas sociales y en territorios alejados de la costa mediterránea, pudiendo mencionarse como ejemplos los santuarios de El-Hofra, Tebessa...como luego veremos. Esta dicotomía puede apreciarse en la propia Iberia púnica, donde el lenguaje iconográfico en ciudades costeras como Gades es de clara influencia helenística, representando un Heracles griego para efigiar a Melkart, mientras que en otras ciudades del interior, como Ilipa, la divinidad femenina mayor, es representada como Tinit en las estelas púnicas de El Hofra, sin forma humana y sí a través de símbolos como caduceos, espigas y astros (figs. 2 y 3$)^{2}$.

\section{Gestos y Signos de PODER Divino}

Permítanme comenzar con el estudio de ciertos signos y gestos de poder divino para los que tenemos buenos ejemplos entre griegos y cartagineses. Me refiero a los dioses que tanto griegos como semitas llamaron epékooi. Una cualidad divina imprescindible para que el diálogo entre el fiel y el dios se inicie, y con él todo el proceso del culto. Es un acto religioso transcendente. El momento en el que la divinidad presta oídos a los clamores del fiel. Esta divinidad que por fin escucha ha sido aludida en todos los cultos; en unos, aquellos que usan la escritura para los usos del culto como los griegos, a través de epítetos divinos; en otros, a través de la hipertrofia del miembro auditivo. No entraré a fondo en el tema de los dioses epékooi puesto que siguen siendo espléndidos repertorios los trabajos de Weinreich y de Lazzarini ${ }^{3}$. El éxito de este epíteto griego, que llevan muchos de sus dioses en inscripciones griegas, fue de tal calibre que llevó a que se aplicase -también en lengua griega- a divinidades orientales como Artemis Efesia, Thea Perasia...; incluso los propios semitas habitando territorios griegos utilizaron el termino para Baal Shamon,

3 O. Weinreich, "Theoi epékooi”, Ath..Mit. 37, 1912, 1-68; M.L. Lazzarini, "Le formule delle dediche votiva". Mem. Ac.Lincei s.8, 19, 1976, 45-354. 
Atargatis, Serapis, Isis 4 . Un epíteto sencillo y corto que equivale en las inscripciones púnicas a la larga frase que justifica la deposición de un exvoto, pero que tiene la misma función y atestigua el mismo proceso religioso: "porque oyó la voz de mi plegaria". Esta fórmula suele estar presente en casi todas las estelas púnicas con epígrafe pero además, algunas de ellas, ilustran las orejas como acróteras del monumento, dándoles claro protagonismo en el motivo del agradecimiento (fig. 4$)^{5}$.

Es indudable que los íberos conocieron también la fórmula universal de rememorar el hecho de que la divinidad haya escuchado y concedido los beneficios solicitados para agradecérselos a los dioses. Por su gratitud o por su compromiso hubieron de utilizar exvotos orales, escritos, de objetos... sin embargo ninguno de ellos se ha identificado todavía.

\section{¿CÓMO SE ILUSTRA EN IMAGINERÍA A LOS DIOSES QUE ESCUCHAN?}

Los griegos no pusieron ningún énfasis en la iconografía de los dioses que prestan oídos, entre otros motivos porque utilizaron mucho el exvoto epigráfico y, ahí sí, hacían constar la cualidad divina de epékoos. Es cierto que en muchas ocasiones dejaron como testimonio del bien recibido un par de orejas. Este es el caso de los exvotos de orejas en santuarios de Apolo y Asclepios, pues ambos están relacionados con los oídos y con la vista, por tener los dos capacidad oracular y también curativa. Respecto a los muchos exvotos en Epidauro, que podrían interpretarse como todos ellos curativos, hemos de insistir en la frecuencia con que Asclepios es llamado epékoos. Este es también el caso de otras divinidades que escuchan y a las que se les dedican pares de orejas junto a inscripciones aclaratorias. Uno de los muchos exvotos del santuraio de Isis en Dion (Macedonia) representa una pareja de orejas (fig. 5) y el texto "Mellichos, hijo de Hipachos a Sarapis, Isis, Anubis".

El concepto de la relación directa entre divinidad y fiel es tan universal que todas las religiones de las que nos han quedado textos literarios o epigráficos parecen haberlo contemplado en el diálogo religioso. Ya hemos citado las palabras de Clemente de Alejandría, quien dice que los

\footnotetext{
4 Weinreich (n. 3) 28.

5 G. Picard, Catalogue du Musée Aloui, nouvelle serie, s/a, s/1. cb 658 .
}

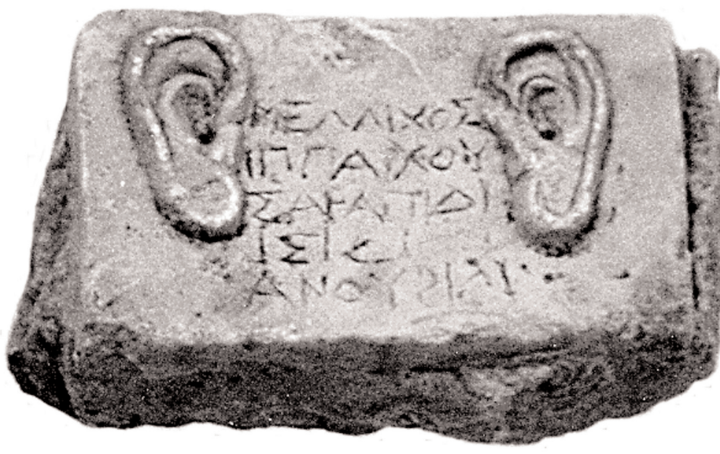

Fig. 5: Orejas del santuario de Isis (Museo de Dion, Macedonia). Foto M.P. García-Bellido.

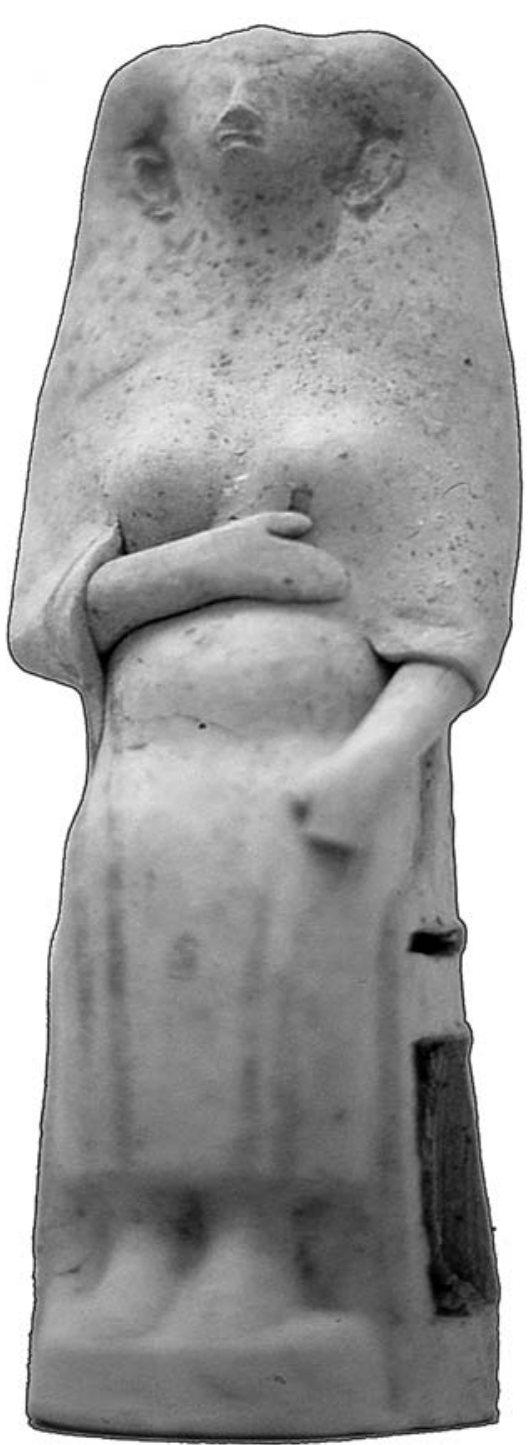

Fig. 6: Terracota procedente de Carthago, s. VII? (Museo del Bardo). Foto M.P. García-Bellido. 
egipcios dedican a sus dioses orejas y ojos para atestiguar que el dios lo ve todo y lo escucha todo. Pues bien, sabemos por la epigrafía que también los dioses galos "prestan oídos" a los fieles, y el hecho es tan importante en la relación devoto-divinidad que así lo hacen constar en sus agradecimientos escritos. Me refiero al célebre
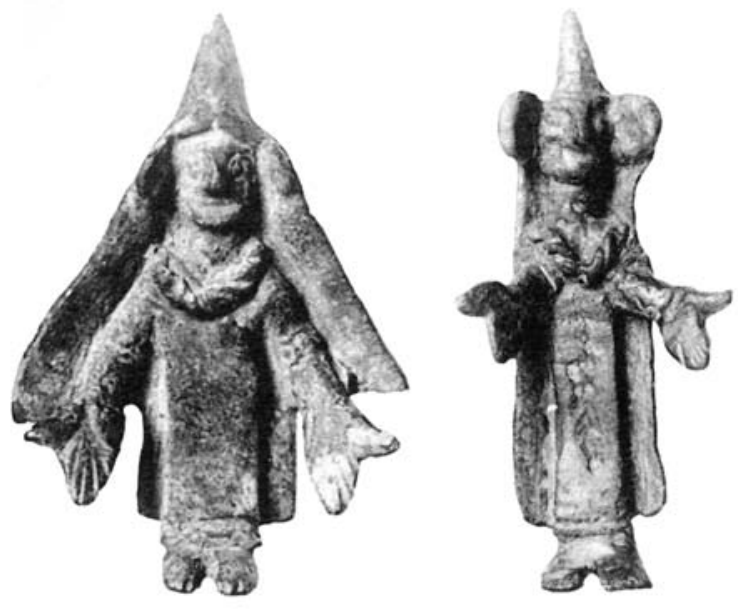

Fig. 7.- Exvotos ibéricos con grandes orejas y manos (Collado de los Jardines, Jaén). Alvarez Ossorio núms. 33-35.

altar de Glanum dedicado a las matres de Glanum rokloisiabo, epíteto que parece ser una traducción al galo del griego epékoois, que "prestan oídos"

Sin embargo, como he dicho, los griegos no introdujeron información directa en la mímica iconográfica referente a esta capacidad, pues una exageración del miembro auditivo hubiera desfigurado la imagen divina. No tenemos en la iconografía griega hipertrofias explicativas de los atributos divinos. Sin embargo los cartagineses no son tan escrupulosos, y algunas terracotas de Carthago podrían interpretarse de esta forma (fig. 6). Me refiero a la divinidad grávida, entronizada y velada que deja ver sus grandes orejas fuera del manto, "desveladas", "destapadas", para poder oír bien el clamor del fiel. No creo

6 J. de Hoz, "Las "madres que prestan oídos". Un epíteto griego traducido al galo", Studia in honorem Ludovici Aegidii edendi curam pareverunt. Editorial Complutense, Madrid 1994, 187-195.

7 Procedente de una tumba de la propia Carthago, aunque se supone que traídas de Fenicia donde el tipo es común; se fecha en el s. VIII aC. por el contexto de la tumba (Mohamed Yacoub, Le musée du Bardo, Tunez

que podamos interpretarla como una muchacha, al igual que Gauckler, pues el hecho de estar entronizada y velada indica que estamos ante una representación de la divinidad, a la que se la muestra encinta ${ }^{7}$. Su aparición en una tumba ha de tener relación con un bien concedido por la divinidad o quizás con la causa del fallecimiento y la solicitud de amparo en el más allá.

Para que veamos lo universal de estas súplicas humanas y respuestas divinas, déjenme poner letra griega a esa imagen cartaginesa. Se trata de un epigrama en que Antipatro de Macedonia (A.P. IX 46) cuenta: "una muchacha ciega y sin descendencia rogó a Artemis epékoos que le concediera la gracia de tener un hijo y, que si ello no era posible, entonces la de recuperar su vista perdida. Artemis, divinidad que ampara los alumbramientos, le concedió las dos gracias". Pues bien, aquí, en esta imagen cartaginesa de la figura 6, la diosa entronizada ¿Ashtart? ¿'Tinit? ¿...? ha escuchado la voz de la plegaria y ha bendecido al fiel, concediéndole la gracia que pedía, charis.

Para todos los fieles resulta imprescindible el que los dioses los oigan desde arriba y para ello el que los dioses desvelen sus orejas. Luciano de Samosta (Icaromenippus 25) relata cómo en el Olimpo, en “...el lugar en el que Zeus debía de sentarse a escuchar las plegarias, había una serie de aberturas, semejantes a bocas de pozos, provistas de tapadera, y al lado de cada una se hallaba un trono de oro. Zeus tomó asiento junto a la primera, retiró la tapa y prestó atención a los suplicantes. Las plegarias que llegaban de todos los puntos de la tierra eran diversas... iOh Zeus que yo alcance el trono! iOh Zeus que crezcan mis cebollas y mis ajos! iOh dioses que mi padre

1996, 27, fig. 15 a). Se trata de dos terracotas que fueron publicadas ya en P. Gauckler, Les necropoles puniques de Carthage, Paris 1915, Pl. 165 (debo y agradezco el dato de su publicación por Gauckler a Isabel Izquierdo). Además en Pl. 163 se ilustra el contexto total de la tumba 350 , tumba que desgraciadamente no parece haber sido descrita en texto. 
muera pronto!”...

Estas creencias del culto popular eran tan habituales que sirvían de prototipo para que las personas más cultas, menos ligadas a la mímica, ridiculizaran estos rituales que conllevaban actitudes supersticiosas. Este es el caso de Seneca (epist. 41, 1) quien atacando las formas vulgares de culto, vuelve a incidir en la importancia de los dioses que escuchan, como paso previo para el diálogo entre devoto y divinidad y nos describe además el gesto ritual de la plegaria, elevando las manos al cielo y no bajándolas como veremos: "No es cuestión de elevar las manos al cielo, ni de suplicar al guardián del santuario para que nos permita acercarnos al oído de la imagen con el pretexto de ser escuchados más favorablemente. Dios está cerca de ti, está contigo, está dentro de ti"

\section{¿SENTÍA EL HOMBRE IBÉRICO LA NECESI- DAD DE SER ATENDIDO POR LA DIVINIDAD EPÉKOOS?}

Sin ninguna duda. La primera necesidad religiosa del individuo es ponerse en contacto con la divinidad para establecer una relación. No existe religión sin diálogo y en él es siempre la divinidad la que atiende, ocurriendo sólo en los hechos extraordinarios o en los oráculos el que la divinidad se deje oír y casi nunca directamente por el fiel.

Es muy posible que los exvotos ibéricos, y no ibéricos, con grandes orejas, fuera o no de sus mantos, sean representaciones de los dioses que han escuchado la voz de la plegaria del fiel, dioses que seguramente tenían un epíteto en ibérico con el mismo significado que epékoois o rokloisia$b o$. Muchos de los exvotos ibéricos están velados, vestidos con manto o con traje de elite y tienen esas enorme orejas desveladas y desplegadas para atender la súplica. Si mi propuesta es correcta, deberíamos cambiar nuestra interpretación tradicional de que se trate de imágenes de fieles y suponer que, cómo en la mayoría de los santuarios mediterráneos, los exvotos suelen

8 Trad. Ismaél Roca, Epistolas morales a Lucilio (libros 1IX, Epístolas 1-80), Biblioteca Clásica Gredos 92. Madrid, 1986.

9 Incluso los objetos importados suelen ser depuestos en relación con la divinidad. Este es el caso en el Heraion de Samos de representaciones en objetos menores de Mut, divinidad egipcia que ya los griegos homologaban con Hera (Diod. 1,15). Mut era la diosa de los cielos y la esposa del dios mayor del panteón, Amon (Ph. Brize, "Archaische Bronzevotive aus dem Heraion von Samos", en G. Bartolini, G. Colona, G. Grottanelli, Atti

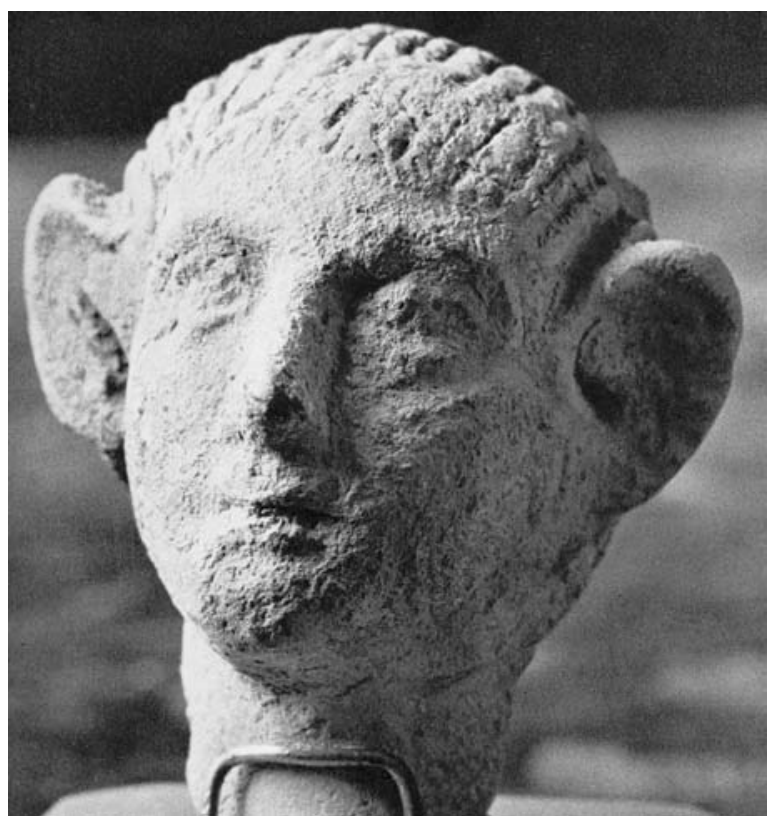

Fig. 8.- Cabeza del santuario de la Serreta de Alcoy (Museo de Alcoy). Tarradell 1968, $n^{\circ} 88$.

consistir en imágenes de la divinidad y no de los suplicantes. Tan es así que las identificaciones de los lugares sagrados mediterráneos se han hecho gracias a la iconografía de sus exvotos que aluden a las características de las imágenes divinas que allí se adoran'.

También en el mundo púnico encontramos las figurillas que ilustran las imágenes del culto. Santuarios con terracotas y exvotos que reproducen la imagen divina, por ejemplo en Henchir Gounifida (Tebessa). Se trata de una estela con representación entronizada de Saturno y Caelestis, ésta identificada gracias a un león que la acompaña. En la favissa de un santuario cercano (Henchir Rohdan) han aparecido numerosas terracotas representando a las dos divinidades, a menudo sentadas como en la estela, con cornucopias, o sujetando a un niño desnudo. Es siempre la representación de esta diosa de la fecundidad, de la abundancia (ops) y la crianza $(\text { nutrix })^{10}$.

del Convegno Internazionale: Anathema. Regime delle offerte e vita del santuari nel Mediterraneo antico, Roma 1989, 321). Recuérdense también las plaquitas (c. $27 \mathrm{~cm})$ de Locri donde se ilustra a Persefone y a Demeter (E. Langlotz, Die Kunst der Westgriechen, München 1963, Taf. 71-73), o de Selinunte con imágenes sentadas con polos y ofrenda divina en la mano $(\mathrm{c} .30 \mathrm{~cm}: \mathrm{ibm}$. Taf. $34,68)$.

10 M. Leglay, Saturne Africain, Paris 1961, Monuments I, p. $349, \mathrm{n}^{\circ} 46$, lám. XIII 5. 

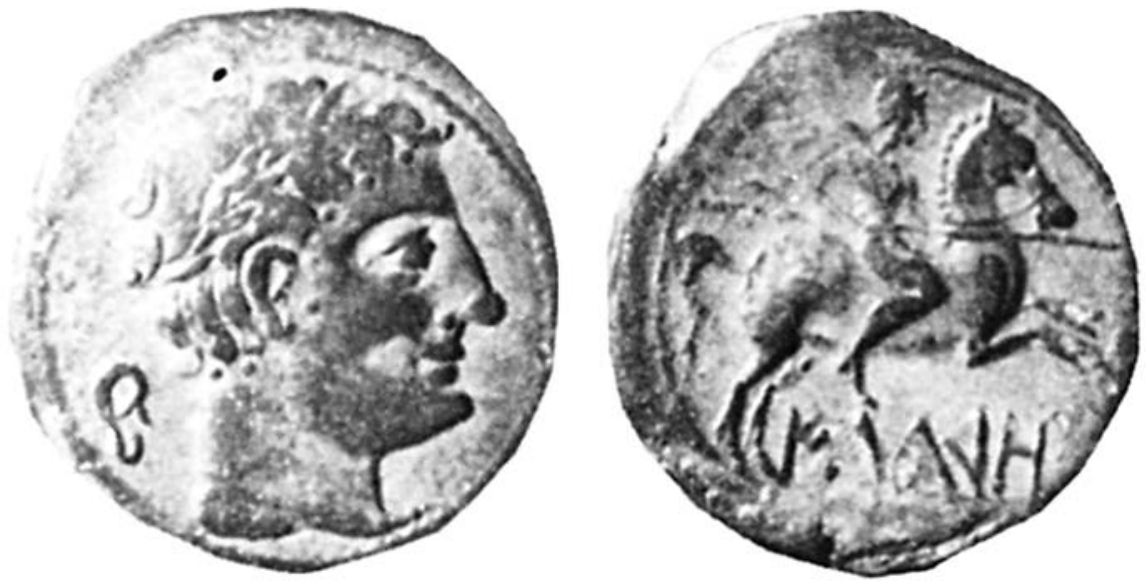

rado sin embargo estas imágenes como representación de las diferentes clases sociales de los donantes y, con ello, las hemos tenido como "retratos" de los fieles ${ }^{13}$.

El mismo juicio me merece la escultura del Santuario de la Serreta de Alcoy (fig. 8) $)^{14}$. Se trata de la cabeza en piedra de un joven, hecha con facciones muy mesuradas, yo diría que más bien reducidas en proporción al tamaño total: ojos, nariz y boca

Fig. 9.- Bronce de Ilturo (prov. Barcelona). Ss. II-I aC, DCyP s.v., núms. 14 y 15. Col. IVDJ. son pequeños. Sin embargo, las orejas son enormes y se despegan

De hecho esta misma diferenciación de tipos existe en los santuarios ibéricos y su estudio podría informarnos sobre el carácter de las divinidades adoradas en cada uno de ellos. Es el caso de los exvotos del Collado de los Jardines (fig. 7) ${ }^{11}$. Se trata de un gran conjunto de figuras de iconografía similar aunque con grandes diferencias de factura, de tamaño y de detalles. Es indudable que proceden de muy distintos talleres aunque reproduzcan una misma imagen, femenina, con túnica ceñida, torques y banda en diagonal, capite velata, dejando salir unas grandes orejas fuera del manto para "prestar oídos", dirigiendo hacia abajo la mirada y sus enormes manos. Las orejas, o su simulacro, mejor que arracadas como a veces se han descrito, tienen un gran protagonismo en la imagen y deben de aludir a la capacidad divina de escuchar al fiel. Más aún, es muy probable que la extrema decoración que encontramos en el arte ibérico concentrada en las orejas pueda tener que ver con el valor inmenso de este órgano divino dentro del ritual del culto. Como más abajo veremos, también la mirada y, sobre todo, las manos tendidas hacia abajo son signos divinos de diálogo y de concesión de beneficios. Es posible incluso que estos exvotos, por su repetitiva iconografía, sean copias burdas de imágenes de culto locales y que por ello haya esta similitud figurativa dentro de ciertos santuarios, similitud y especificidad que ya observó Lantier ${ }^{12}$. Hasta hoy se han conside-

\footnotetext{
11 F. Alvarez Ossorio, Catálogo de los exvotos de bronce ibéricos del Museo Arqueológico Nacional, Madrid 1941, núms. 33-35.
} del cráneo para "prestar oídos". Yo ofrecería aquí, como en los exvotos anteriores, la propuesta de ver en estas imágenes representaciones de divinidades epékooi y no la de simples devotos.

Un último testimonio quiero presentar, cuyo valor reside en el carácter claramente oficial de la imagen. Se trata de una moneda de ilturo (Burriac, Mataró) del tránsito del s. II al I aC. (DCyP s.v.). La ciudad había comenzado sus acuñaciones en el s. II colocando en anverso el símbolo de un jabalí, sin que sepamos su significado. Después la ceca acuña sin símbolos, pero en la última emisión, posiblemente del tránsito de los siglos II-I aC., tiene lugar una acuñación de muy buena calidad (fig. 9) y en ella, unidades y cuartos, muestran una oreja como símbolo. Es indudable que se refiere a la imagen laureada que reproduce el anverso, posiblemente la divinidad patrona de la ciudad. Lo que es seguro es que no se trata de un devoto. El símbolo ha de ponerse en relación, como mencionaremos para Arsa más abajo, con algún episodio de la historia de la ciudad, en el que el dios escuchó la plegaria del pueblo y concedió la gracia o previno, con su oído presto, la catástrofe.

\section{¿SON CONSCIENTES LOS FIELES DE QUE LOS DIOSES SON PANÓPTAI?}

Volvamos al texto de Clemente de Alejandría en el que se recuerda que los exvotos de orejas y
12 R. Lantier, Bronzes votifs ibériques, Paris 1935, 20s.
13 Ibm.
14 M. Tarradell, Arte ibérico, Barcelona 1968, n 88. 
ojos aluden y agradecen el que los dioses lo oigan y lo vean todo, para incidir, esta vez, en el énfasis que la imaginería pone a veces en las divinidades que observan, panóptai. Como hemos señalado, es la literatura la que ha ayudado a conocer estas cualidades de los dioses, dado que en la imaginería griega tampoco encontramos rasgos hipertróficos de los ojos.

Son llamados panóptai los dioses en la Iliada (3,276 ss.) "Sol, lo ves todo y todo lo oyes", dioses que observan desde arriba a los mortales, bien para perseguir la injusticia o favorecer la clemencia y, sobre todo, para ayudar en los sufrimientos humanos; por ello su mención en las tragedias es muy frecuente (Esq. Eu. 1045, Supp. 139). También es muy usado por Esquilo el verbo epopteuein (Orestea: 224, Ch. 985, 489, 583; $A g$. 1270) ) con el mismo sentido benéfico de divinidades vigilantes del bien y el mal ${ }^{15}$.

Sin embargo, es en culturas colindantes a la griega, con una mímica menos mesurada, donde podemos identificar la representación figurada de este concepto. De nuevo el mundo céltico-galo nos proporciona imágenes divinas que han sufrido una interpretatio Romana, pero que son fácilmente identificables con las galas, gracias, en parte, a los relatos de César.

Sólo mencionaré el epígrafe de la pátera hallada en Chateaubleau (Seine-etMarne), un yacimiento galoromano con varios santuarios de tradición local. La dedicatoria se hace en latín: Deo Mercurio solitumaro Augusto. La epíclesis solitumaros en galo, que tambiên se conoce en Bath, parece proceder de soli"ojo" y maro "grande"16. Pues bien, en el mismo santuario han aparecido exvotos de Mercurio, recognoscible por unas pequeñas alas en el cabello, cuya hipertrofia de los ojos explicaría ahora, con la inscripción de la pátera en la mano, el carácter panóptero que poseía la divinidad en ese santuario (fig. 10). Es muy posible que este Mercurio sea una de las interpretationes que la divinidad mayor Lugus, provocó en la religión romana, según nos dice César.

Para los editores de la inscripción, la figura de Mercurio, de producción local, repetía en peque-

15 A.H. Sommerstein, Aeschylus. Eumenides, p. 120.

16 D. Gricourt, D. Hollard, F. Pilon, "Le Mercure Solitumaros de Châteaubleau (Seine-et-Marne): Lucus

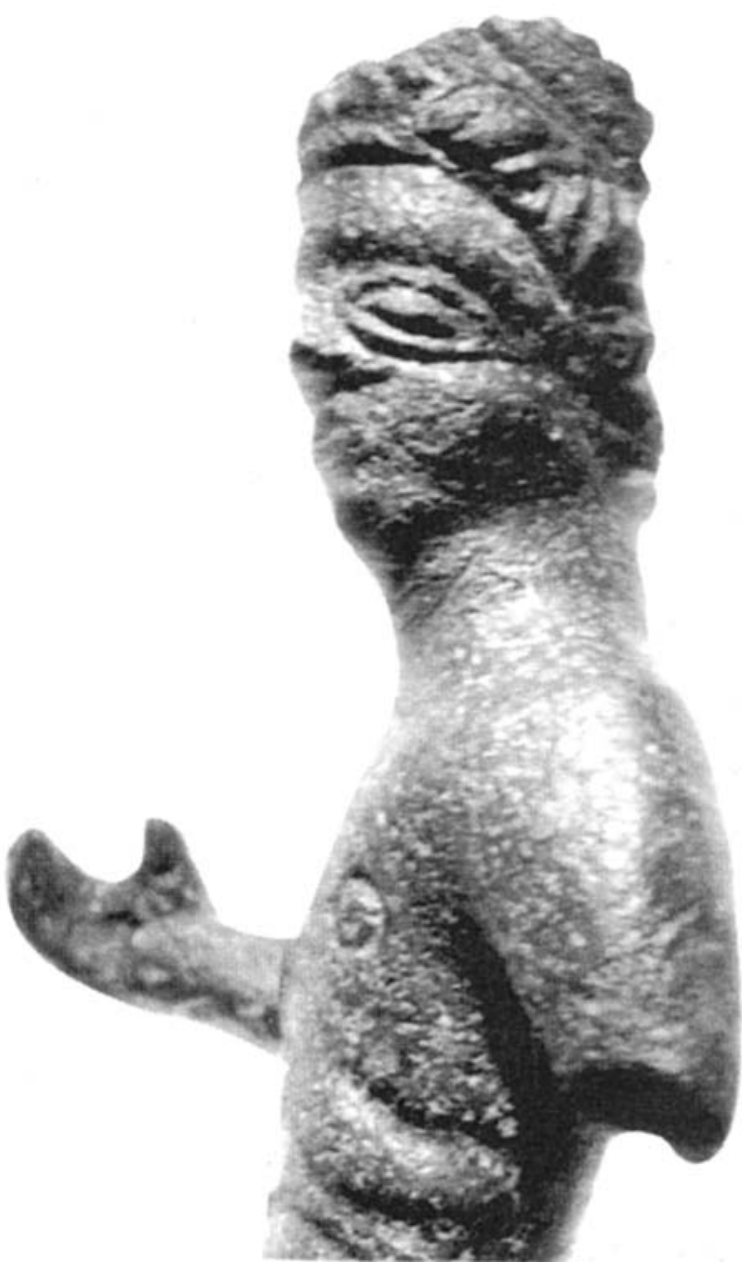

Fig. 10.- Imagen de Mercurio solitumaro del santuario de Chateaubleau (Seine et Marne). Gricourt \& Hollard \& Pilon.

ño la imagen expuesta en el santuario pues, para las fechas del santuario proporcionadas por las monedas, hemos de pensar en ss. II-IV, de manera que el santuario debía ya entonces poseer imágenes de culto. Una interpretación similar se ha dado a los innumerables y repetitivos exvotos de Mercurio del santuario de Arvernes, todos iguales $\mathrm{y}$, posiblemente, reproducciones de la imagen de culto, o el de Hercules Borvo, cuya imagen cultual, ésta sí, apareció dentro de la piscina de las termas romanas, módelo de los innumerables exvotos que se encuentran en el mismo santuario ${ }^{17}$.

No he querido atestiguar aquí exvotos ibéricos cuyos grandes ojos pudieran ser interpretados como de divinidades panópteras o solitumaras, pues son equívocos. Sí me ha parecido que la

macrophtalme, visionnaire et guérisseur". Dialogues d'Histoire Ancienne 25/2, 1999, 127-180.

17 Ibidem. 
moneda de Arsa puede traerse a colación (fig. 11). Parece claro por lo frontal del ojo y su expresiva decoración circular que no estamos ante un mal hacer, sino ante una voluntad de expresión del abridor de cuños. Arsa es una ciudad situada en la Beturia túrdula, cuyas monedas muestran su topónimo escrito en latín y en neopúnico (libiofenice). Sin duda su cultura era turdetanopunica (DCyP s.v. arsa y turdulos). No puedo traer paralelos locales pero creo que también en este caso debemos ver una representación del mismo concepto, concepto y forma que parecen haber sido universales ¿Cómo se justifica el qué en una moneda se represente una divinidad panóptes? No lo sabemos, pero de manera similar a lo que hemos visto en las orejas de las monedas de Ilturo, la alusión puede ser coyuntural o si queremos mítica, de la misma manera que los gansos lo fueron en la iconografía romana. De esta ciudad no tenemos sino esta emisión que podría fecharse en las guerras sertorianas. No es imposible que la ciudad se salvase de un asedio o de una derrota por ciertos signos visuales atribuidos a la benevolencia de su divinidad protectora.

\section{¿DO UT DES O DO ET DAS? LA IMPORTANCIA RELIGIOSA DE LA DÁDIVA DIVINA}

Permítanme terminar con el comentario de otra frecuente exageración de miembros en las imágenes ibéricas. Me refiero a las grandes manos de muchos de nuestros exvotos (fig. 7). Son las figuras con esta precisa iconografía las que se acumulan en el santuario de Collado de los Jardines pero también en Santiesteban. Creo que la imagen ha de interpretarse como la de una divinidad que tras haber escuchado al fiel que está en el ámbito terrenal, se dirige a él y le tiende las manos con los dones que ha implorado. Para esta interpretación que propongo también tenemos testimonios literarios y epigráficos en el mundo griego que nos pueden ayudar a comprender el gesto. Son varias las epícleseis que se utilizan. Dotér: Himn. Homerico 8; Pindaro, Pean 7,1; Esquilo Prom. 612; Dion. Halicarn. 2,62 "dios dador de todo bien"; dóteira en fem.: Hesiodo (trab. 356); dotikós "dadivosos", Aris. EN $1121^{\mathrm{b}} 16$.

Es posiblemente, tras la actitud de epékoos, la primera forma de establecer contacto en la que el fiel pide y el dios da o, al revés, el hombre empieza dando y el dios responde. Esta forma de

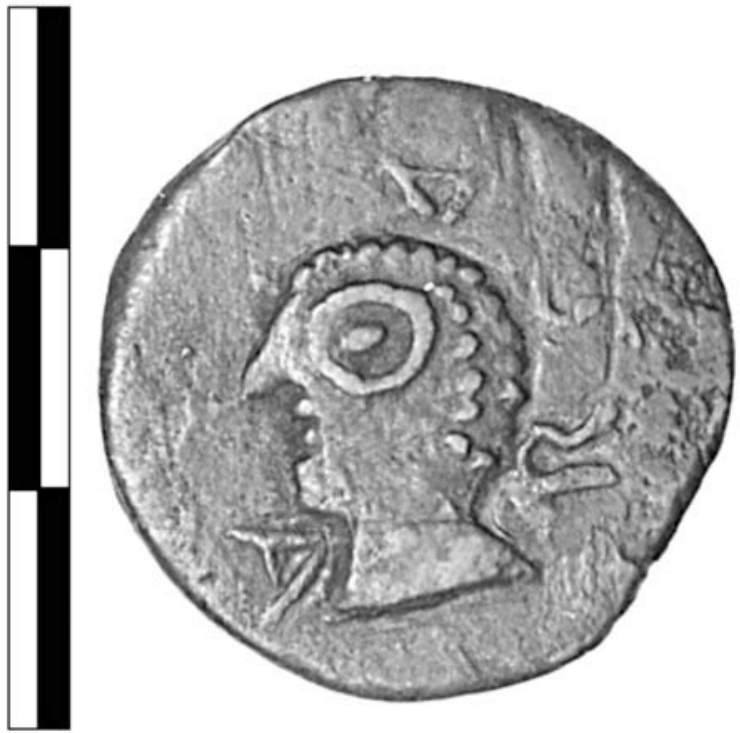

Fig. 11.- Bronce de Arsa (prov. Badajoz). S. I aC. (DCyP s.v. $\mathrm{n}^{0} 1$ Col. IVDJ.

transmisión de los bienes y regalos entre divinidades y fieles ha sido largamente discutida, y un artículo de Burnett Taylor que caracterizó el problema del sacrificio como do ut des ha levantado mucha polémica en el cómo se estable la reciprocidad del bien divino y el don humano. No entraremos aquí en ello, pero es naturalmente admitido que una de las características principales de la divinidad consiste en la dádiva. Dádiva que Lazzarini y Grottanelli a través de las frecuentes inscripciones de sacrificios han tipificado gracias al léxico utilizado en ${ }^{18}$ :

a) las que utilizan el verbo chaíro, del que proceden las muchas inscripciones que mencionan la cháris = gracia, caridad.

b) las que usan soxo = salvar

c) el verbo dídomi y sus derivados $=$ dar, conceder

Estos términos griegos son similares, aunque mas variados, a los usados en inscripciones púnicas en las que el fiel relata que la divinidad escuchó (shama) sus palabras y le bendijo ( brk), le concedió el bien.

De nuevo nos faltan en la imaginería griega datos identificativos de esta benevolencia. Gerhard Neumann constata en su célebre estudio sobre Gesten und Gebärden in der griechischen Kunst que efectivamente faltan estos gesto divinos que identifiquen las acciones de los dioses, posible-

18 M.L. Lazzarini, "Iscrizioni votive greche", en G. Grottanelli, “Do ut des?” en Ibidem 45-54. 
mente por miedo a la fuerza de la imagen. Se temen las consecuencias de la exageración del gesto y por ello se prefiere representar la vida y acciones de los dioses como actos cotidianos, intrascendentes. Muy pocos gestos pueden tipificarse. Sí, el del suplicante con las manos extendidas hacia arriba y las palmas mirando al dios, como nos describe Séneca, y parece haberse mantenido vivo en las formas actuales de culto, al igual que la mirada dirigida a lo alto como gesto de súplica.

A pesar de esta precisa descripción de Séneca la simbología de las manos es quizás la más difícil de interpretar, sin duda porque no es unívoca. Neumann supone que las figuritas, cuyos brazos van pegados al cuerpo y sujetan con una mano una ofrenda, pueden ser divinidades, incluso representaciones de una imagen cultual, un xoanon. Para esta deducción toma como ejemplo el naiskos del templo de Hera de Chidonia, dentro del cual se observa una figura femenina con polos y vestida como la dama de Auxerre, figura divina que posiblemente reproduce la imagen del santuario, representada en el acto de dádiva. Sería caracterizada como charis $^{19}$.

También las estelas púnicas, exvotos a la divinidad porque escuchó su plegaria y le bendijo, muestran la mano derecha y el antebrazo divinos, signo de su omnipontencia, símbolo de pantócrator (fig. 4). Es la forma tradicional de la bendición divina, la misma que debemos interpretar, creo yo, en la imagen de Despeñaperros (fig. 12). Se trata de un exvoto salido en las excavaciones de Cabré cuya factura es muy buena y sus gestos claros. La imagen tocada con velo y alta diadema mira hacia abajo bendiciendo con su mano derecha al humano ${ }^{20}$. Esta es la bendición que no significa sino la promesa de la concesión de los bienes, que no tienen porqué ser materiales, en un gesto que todavía hoy es válido en nuestras religiones. Sus pies desnudos vienen a confirmar esa posible esencia divina.

Pero es en el texto de la naos de madera de

19 G. Neumann, Gesten und Gebärden in der Griechischen Kunst (Berlin 1965) 82.

20 I. Calvo \& J. Cabré, "Excavaciones arqueológicas en en Collado de los Jardines (Despeñaperros)", Junta

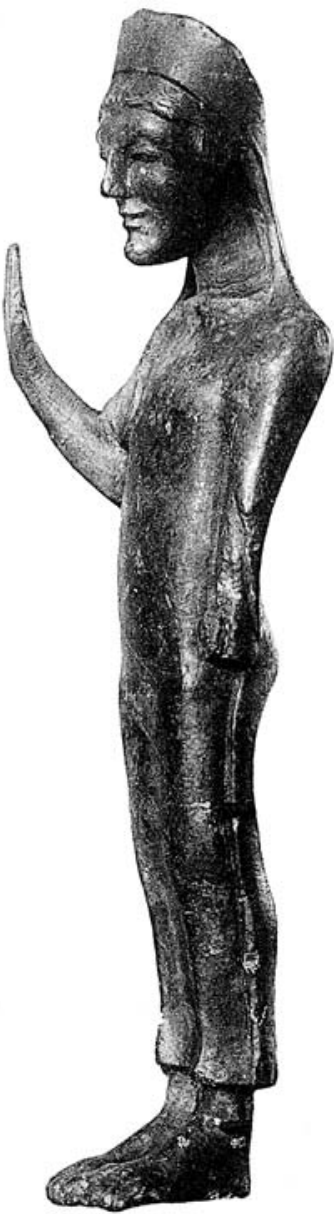

Fig. 12.- Exvoto de Collado de los Jardines (Alvárez Ossorio $n^{0}$ 17).

Turín dedicada a Res y a Amon, donde encontramos posiblemente el paralelo escrito para nuestras imágenes ibéricas. En él se invoca a la divinidad como "quien oye la suplica, quien tiende la mano al insignificante, quien salva al exausto ${ }^{21}$. Es en esta súplica escrita donde encontramos, creo yo, la descripción del gesto de los exvotos ibéricos, de aquellos capite velata y mirada hacia abajo, torques, banda cruzada sobre el pecho y las grandes manos llenas de beneficios espirituales o materiales tendidas al fiel. Imagen y palabras que los griegos entendían tras los epítetos de dóter, doitikos o pantochrator.

En algunos de estos exvotos ibéricos, sobre todo en los masculinos, la imagen parece representar por su vulgaridad a un fiel, a un orante,

Superior de Excavaciones y Antigüedades, Memorias 1918, ${ }^{\circ}$ 2, L. 20; Alvarez Osorio, cit. (n. 11) n 17.

21 A.Erman; Aegyptische Religion 63, Abb. 56, Abb.1. 


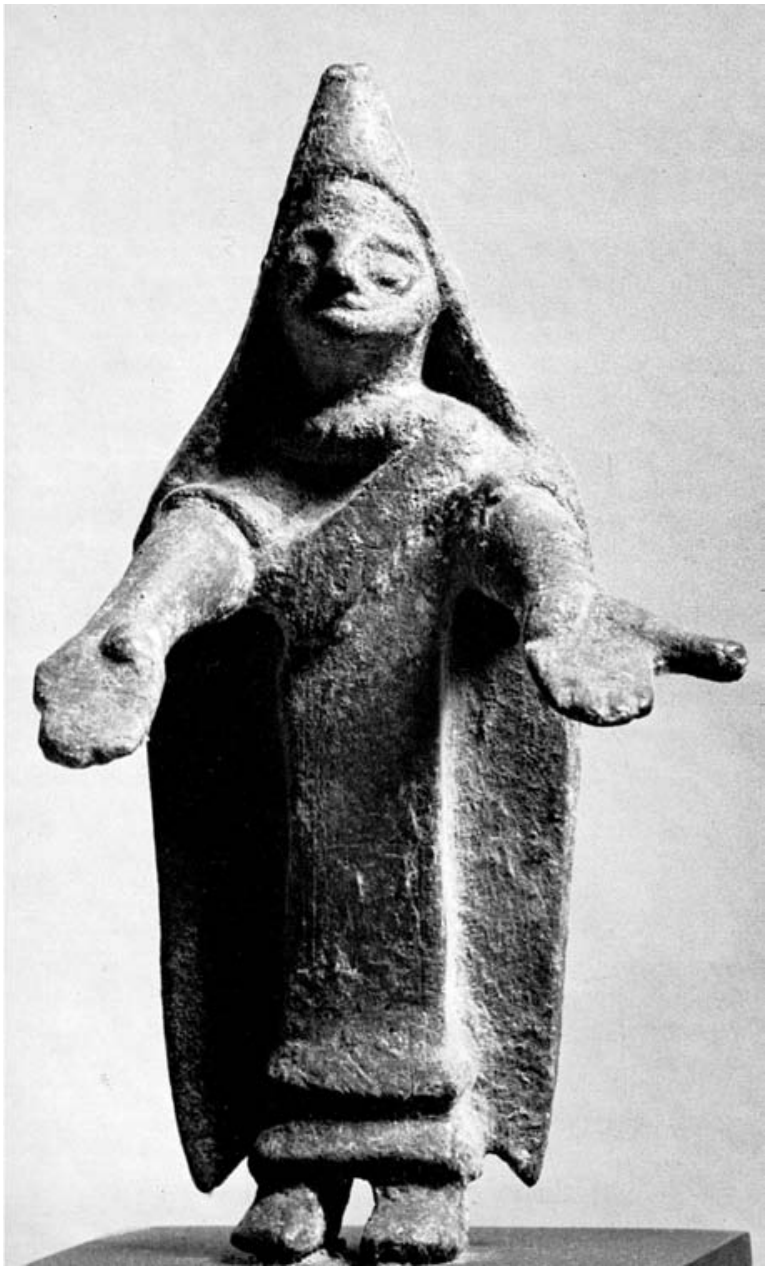

Fig. 13.- Exvoto de Castillar de Santiesteban (Museo arqueológico de Barcelona). Tarradell 1968, $n^{0} 106$.

como normalmente se las ha descrito. Sin embargo no olvidemos, como refiere Neumann, que, gracias a la influencia griega clásica y helenística, la imagen de los dioses se humaniza y vulgariza. Los dioses se visten como las oferentes y se acercan a ofrecer libaciones en los altares de otros dioses. Las actitudes divinas se hacen humanas y cotidianas pues basta un símbolo para que podamos identificar a la divinidad. Sin embargo el oferente ibérico del exvoto necesita enfatizar al menos la parte esencial de la figura divina que ha producido el bien, en este caso las manos (fig. 13).

Hemos visto que la descripción de Séneca (epist. 41, 1) sigue siendo válida para los gestos actuales del culto. También actual es la imagen de estos exvotos ibéricos en el esquema de su representación, con la mirada y las manos tendidas hacia el fiel. La religión cristiana, que tanta

22 G. Nicolini, Les bronzes figurés des sanctuaires ibériques, Paris 1969, p. 259

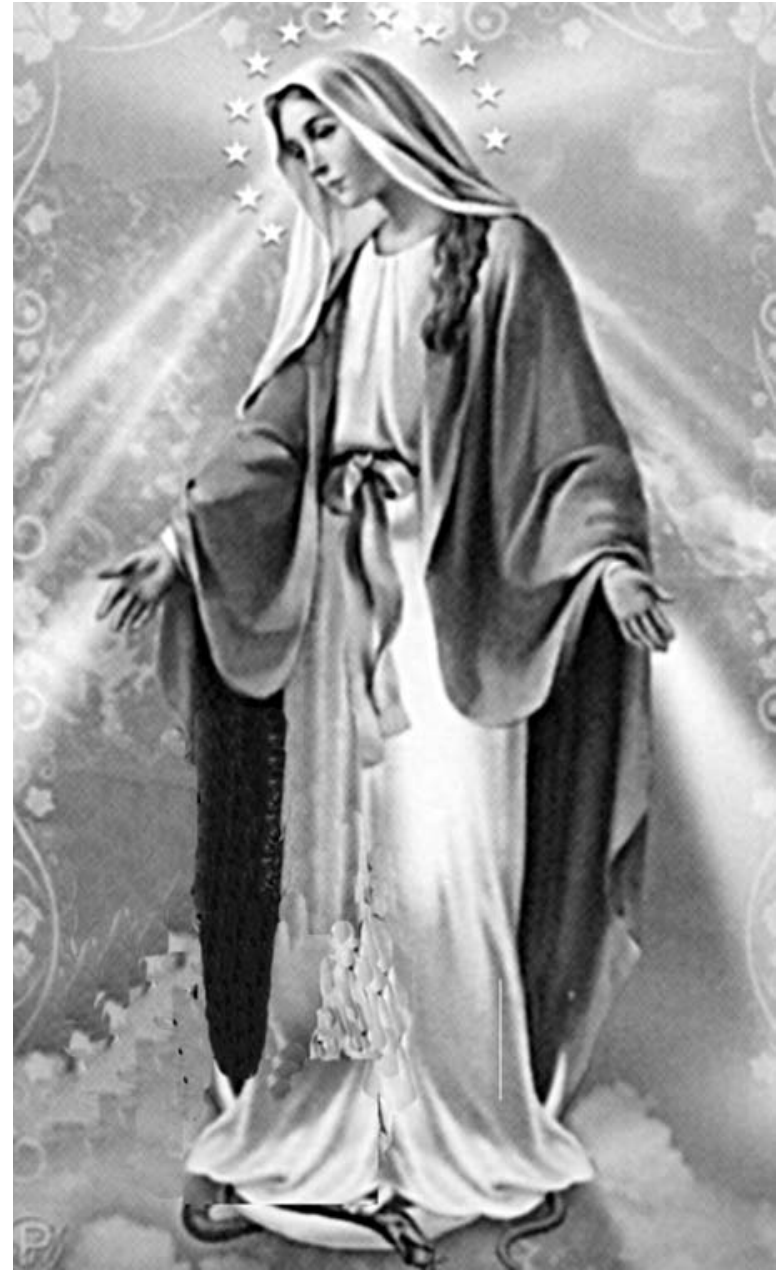

Fig. 14.- Virgen de la Caridad, llamada $N^{a}$ Sra de los milagros.

iconografía oriental y clásica retiene, efigia a la Virgen de la Caridad (charis), advocada y querida en todos los hospitales y conventos de las Hermanas de la Caridad, de manera similar a los exvotos que comentamos (fig. 14): manto que le cubre la cabeza, la mirada dirigida al ámbito terrenal, al igual que las manos con las que les concede los dones que le han solicitado. Los gestos divinos siguen siendo los mismos, aún hoy en día, por la claridad y expresividad de su mímica.

\section{Epílogo}

Todos estos gestos han sido naturalmente observados y comentados por los estudiosos que se han ocupado del tema. Es sin duda Nicolini quien más se ha extendido sobre ellos:

L'homme doit voir la divinité, son regard doit l'implorer: on lui donne donc des yeux pour cela. Il doit aussi l'entendre; ses oreilles seront très soignées, figurées sur la mitre ou sur les cheveux, ou bien faites d'un simple trou dans la tête... ${ }^{22}$. Sin embargo, en casi ninguna religión la 
contemplación directa de dios está al arbitrio del fiel. Las epifanías divinas son actos tan raros que son considerados como milagrosos o propios sólo de ciertas fiestas. Es dios quien vigila y para ello es panopter o panderkes, y quien escucha, epekoos, todos ellos epítetos divinos frecuentes, como hemos visto, de capacidades magnificadas, más propias de los dioses que de los fieles y que no se encuentran referidos a los actos humanos en el culto.

\section{LA DESNUDEZ Y LA FRONTALIDAD}

Otras características de la imaginería ibérica podrían ponerse también en relación con la esencia divina de sus representaciones. Me refiero desde luego a la desnudez y también a la frontalidad. Ambas han sido tratadas por Lantier, Nicolini y Prados. Lantier señala (p. 20) que la desnudez es muy rara en Castillar de Santiesteban, inexistente en El Cerro de los Santos pero muy frecuente en Despeñaperros. Es evidente que tenemos aquí una caracterización del culto de estos santuarios, siendo muy posible que la divinidad de este último lugar fuera advocada por sus beneficios de fertilidad y que la desnudez fuera una de las formas en las que la divinidad de la naturaleza se presentaba al fiel. Recuérdese que en el santuario de Ikaros, y lo menciono por la similitud de la iconografía de sus exvotos con los ibéricos, uno de los conjuntos lo forman las figuritas femeninas de terracotta que pegan sus manos a los flancos y muestran su desnudez, sujetándose una de ellas los senos con las dos manos, al igual que las de Collado de los Jardines. A este conjunto se suma en Ikaros el de los jinetes y el de los animales, más otro de brazos y manos. El nombre de la divinidad se desconoce pero se ha supuesto que tuviera relación con $\mathrm{Artemis}^{23}$. Es muy posible también que en Jaén una divinidad del bosque, que ampara la naturaleza y con ello la fertilidad de hombres y animales, fuera la adorada en estos santuarios ibéricos, especialmente en el de Despeñaperros donde son más frecuentes las figuras desnudas; una divinidad de la naturaleza pura habría provocado las representaciones que nos ocupan

$L a$ frontalidad es otra de las carácterísticas mencionadas por los estudiosos del tema. En algunos casos se ha traído a colación el paralelo

\footnotetext{
23 H.E.Mathiensen, Ikaros. The hellenistic Settlements, I: The terracotta figurines, Copenhagen 1982, 18s.

24 Lantier 20; Prados 142

25 Sí debería haber incluido los gestos y símbolos de los guerreros, a caballo y a pié, para los que hubiera podi-
}

de los xoana arcaicos pero sólo desde el punto de vista formal y no el del contenido. Nicolini (p. 259) dice: le savant que étudie la statuette parle d'un art frontal, mais que signifie cette "frontalité"... mais une intention de tourner l'image de dévot vers le dieu? Sin embargo, la similitud de la forma del vestido, con pequeñas variantes de manto corto o largo, tiara o velo sin tocado, podría hacer suponer que efectivamente los simulacros de los santuarios hubieran sido xoana con cuerpo de madera donde se ha grabado la desnudez, al que se articulaban los miembros y se vestía en casos de diferentes formas según las ocasiones. Esta era la forma arcaica del culto. Ello conllevaba una clara frontalidad pues el fiel no veía sino la parte delantera de la divinidad. Es indudable que los vestidos regalados -como el manto a Atenea- reproducían la vestimenta de la elite social, tanto la masculina como la femenina. Las divinidades hasta el s. XVII se han ilustrado con ropajes coetáneos a los de los fieles que los adoran. Por ello estos exvotos son un precioso testimonio de los hábitos de vestido de los íberos contemporáneos, causa de la gran dificultad de interpretación iconológica que tenemos hoy. Sólo ciertas características como la desnudez y, sobre todo la mímica, las hipertrofias, pueden ayudarnos a diferenciar divinidades de devotos.

Aunque los exvotos ibéricos de los tres santuarios Collado de los Jardines y Castellar de Santiesteban (Jaén) parecen haber sido muy similares, y dentro de esta homogeneidad se ha enfocado siempre su estudio, ciertas preferencias que fueron ya constatadas por Lantier denotan una cierta especificidad en tipo de exvoto. Como ejemplo diré que Lantier y Prados resaltaron el hecho de que los jinetes estén ausentes en Castellar y haya muy pocos en Collado de los Jardines, siendo los más numerosos los procedentes de la Luz; de la misma manera que es Collado de los Jardines el lugar que proporciona más figuras femeninas desnudas o con manto y manos extendidas $^{24}$. Es indudable que una especificidad de esta categoría ha de estar en relación con el carácter divino del culto y no con la sociedad que los ofrece como ha sido la interpretación generalizada desde Lantier. Sin embargo el estudio de esta especificidad rebasa el objetivo de estas líneas, cuyo fin no es sino llamar la atención sobre los gestos, la mímica, de estas imágenes ibéricas ${ }^{25}$.

do traer a colación tantas imágenes oficiales hechas en las monedas de divinidades y patronos ciudadanos efigiados como jinetes y con armas, de manera casi idéntica a las representaciones de los exvotos; ello queda para otra ocasión. 


\section{Bibliografía}

Alvarez Ossorio, F. (1941): Catálogo de los exvotos de bronce ibéricos del Museo Arqueológico Nacional, Madrid.

Bartolini G. \& Colona, G. \& Grottanelli, C. (1989): Atti del Convegno Internazionale: Anathema. Regime delle offerte e vita del santuari nel Mediterraneo antico. Roma.

Berthier A.\& CHARlier, R. (1955): Le sanctuaire d'El Hofra à Constantine, Paris.

BRIzE PH. (1989): "Archaische Bronzevotive aus dem Heraion von Samos”, en Bartolini G. \& Colona, G. \& Grottanelli, G. **

Calvo, I \& Cabré, J. (1918): "Excavaciones arqueológicas en en Collado de los Jardines (Despeñaperros)", Junta Superior de Excavaciones y Antigüedades, Memorias $n^{\circ}$ 2, 1918, Madrid.

Erman A: Aegyptische Religion 63, Abb. 56, Abb.1.

GaucKler, P. (1915): Les necropoles puniques de Carthage, Paris

García-Bellido M.P. \& BlázQuez, C. (1991): Diccionario de cecas y pueblos hispánicos (DCyP) Madrid.

Gricourt, D. \& Hollard, D. \& F. Pilon, (1999): "Le Mercure Solitumaros de Châteaubleau (Seine-etMarne): Lucus macrophtalme, visionnaire et guérisseur". Dialogues d'Histoire Ancienne 25/2, 127-180.

Grottanelli, C. (1989): “Do ut des?” en G. Bartolini, G. Colona, C. Grottanelli, 45-54.

Hoz, J. DE (1994): "Las "madres que prestan oídos”. Un epíteto griego traducido al galo", Studia in honorem Ludovici Aegidii edendi curam pareverunt. Editorial Complutense, Madrid, 187-195.

LANGLOtZ, E. (1963): Die Kunst der Westgriechen, München

LANTIER, R. (1935): Bronzes votifs ibériques, Paris .

LAZZARINI, M.L. (1976): "Le formule delle dediche votiva”. Mem. Ac.Lincei s.8, 19, 45-354.

(1989): "Iscrizioni votive greche", en G. Bartolini, G. Colona, C. Grottanelli, 845-860.

Leglay, M. (1961): Saturne Africain, Monuments I, Paris.

Mathiensen, H.E. (1982): Ikaros. The hellenistic Settlements, I: The terracotta figurines, Copenhagen.

Neumann, G. (1965): Gesten und Gebärden in der griechischen Kunst. Berlin.

NiCOLINI, G. (1969): Les bronzes figurés des sanctuaires ibériques, Paris.

Picard, G. (s/a): Catalogue du Musée Aloui, nouvelle serie, $\mathrm{s} / 1$.

Prados, L. (1992): Exvotos ibéricos de bronce del Museo Arqueológico Nacional, Madrid.

RocA, I. (1986): Seneca, Epistolas morales a Lucilio (libros 1-IX, Epístolas 1-80), Biblioteca Clásica Gredos 92. Madrid.

Sommerstein, A.H. Aeschylus. Eumenides, p. 120.

Weinreich, O. (1912): “Theoi epekooi”, Ath..Mit. 37, 168

Yacoub, M.(1996): Le musée du Bardo, Tunez. 